\title{
A precise bathymetric map of the world's deepest seafloor, Challenger Deep in the Mariana Trench
}

\author{
Masao Nakanishi \\ Graduate School of Science, Chiba University \\ 1-33 Yayoi-cho, Inage-ku, Chiba 263-8522, Japan \\ e-mail: nakanisi@earth.s.chiba-u.ac.jp \\ tel: $1-43-290-2850$ \\ fax: $1-43-290-2859$ \\ Jun Hashimoto \\ Faculty of Fisheries, Nagasaki University \\ 1-14 Bunkyo-machi, Nagasaki 852-8521, Japan \\ Accepted for publication in Marine Geophysical Research on 10 April 2011
}

\begin{abstract}
Data from three bathymetric surveys by R/V Kairei using a 12-kHz multibeam echosounder and differential GPS were used to create an improved topographic model of the Challenger Deep in the southwestern part of the Mariana Trench, which is known as the deepest seafloor in the world. The strike of most of the elongated structures related to plate bending accompanied by subduction of the Pacific plate is $\mathrm{N} 70^{\circ} \mathrm{E}$ and is not parallel to the trench axis. The bending-related structures were formed by reactivation of seafloor spreading fabric. Challenger Deep consists of three en echelon depressions along the trench axis, each of which is $6-10 \mathrm{~km}$ long, about $2 \mathrm{~km}$ wide, and deeper than $10,850 \mathrm{~m}$. The eastern depression is the deepest, with a depth of $10,920 \pm 5 \mathrm{~m}$.
\end{abstract}

\section{Introduction}

Challenger Deep in the southwestern section of the Mariana Trench is recognized as the deepest seafloor in the world (Fig. 1). The trench is the boundary where the Pacific plate is subducting under the Philippine Sea plate. The pioneer British exploring ship Challenger visited the region during her 1873-1876 world voyage and found a bottom depth of about 8,200 $\mathrm{m}$ by sounding line (Thomson and Murray 1895: Table 1). In 1951, another British ship, the Admiralty's HMS Challenger, did echosounding and explosives profiling and found a maximum depth of 10,863 \pm 35 m (Carruthers and Lawford 1952; Gaskell et al. 1953) In recognition of the work conducted on these two ships, the basin has been called Challenger Deep since 1952. In 1957, the Soviet R/V Vitiaz logged a maximum depth of $11,034 \pm 50 \mathrm{~m}$ at $11^{\circ} 20.9^{\prime} \mathrm{N}, 142^{\circ} 11.5^{\prime} \mathrm{E}$ (Hanson et al. 1959). However, no cruise since has reported a seafloor depth exceeding 11,000 $\mathrm{m}$ in Challenger Deep. Bathymetric measurements using bomb-sounding and a frequency-controlled depth recorder on R/V Stranger in August 1959 and R/V Spencer F. Baird in 1962 revealed the deepest seafloor in two sedimented axial ponds to be 10,915 $\pm 10 \mathrm{~m}$ (Fisher and Hess 1963). A bathymetric survey by R/V Stranger in 1959 found two, possibly three, small elongated depressions deeper than 10,800 $\mathrm{m}$ between $142^{\circ} 35^{\prime} \mathrm{E}$ and $142^{\circ} 05^{\prime} \mathrm{E}$ (Fisher 2009). In January 1960 , the bathyscaph Trieste reached seafloor in the western pocket and logged the depth as $10,913 \pm 5 \mathrm{~m}$ using a manometer to record pressure (Table 2). Using a precision depth recorder with satellite positioning, the R/V Thomas Washington mapped one or possibly two axial basins with a depth of $10,915 \pm 10 \mathrm{~m}$ in 1975 and 1980 (R. L. Fisher personal communication, 1998, 2010). In 1984, S/V Takuyo, from the Hydrographic Department of Japan, found three depressions with floors deeper than $10,900 \mathrm{~m}$ in Challenger Deep (Hydrographic Department, 1984). The ship employed a multibeam echosounder and reported a maximum depth of $10,924 \pm 10 \mathrm{~m}$ at $11^{\circ} 22.4^{\prime} \mathrm{N}, 142^{\circ} 35.5^{\prime} \mathrm{E}$ in the eastern depression. Prior to the Takuyo survey, the deepest spot had been thought to be in the western depression. In 1983, the General Bathymetric Chart of the Oceans (GEBCO) Guiding Committee, considering the results of the survey by $\mathrm{S} / \mathrm{V}$ Takuyo together with those by $\mathrm{R} / \mathrm{V}$ Thomas Washington, concluded the maximum depth of Challenger Deep should be accepted as 10,920 \pm $10 \mathrm{~m}$ (R. L. Fisher personal communication, 1998, 2010). Soon thereafter, several bathymetric 
investigators reported different positions and depths in this area (e.g., Fujimoto et al. 1993; Fujioka et al. 2002; Taira et al. 2005), arguably leaving the exact location and depth of the deepest seafloor unresolved.

Previous seismic and bathymetric studies (Fryer et al. 2003; Gvirtzman and Stern 2004; Miller et al. 2006) show an N-S trending tear in the slab around the southern part of the Mariana Trench. They suggest that the cause of the great depth of the Challenger Deep is partly a result of the subducting lithosphere in the southern part of the Mariana Trench tearing away from the northern part.

The remotely operated vehicle (ROV) Kaiko dived in the Challenger Deep for biological studies during three cruises of R/V Kairei in 1998, 1999, and 2002 (Hashimoto 1998, 2002; Barry and Hashimoto 2009: Table 2). Bathymetric surveys using a multibeam echosounder on $\mathrm{R} / \mathrm{V}$ Kairei examined the topography of the outer slope of the southern Mariana Trench. In this paper, we describe the topographic expression of the outer slope and identify the deepest seafloor using the bathymetric data obtained during the three cruises.

\section{Data and Methods}

A regional bathymetric survey of the Challenger Deep was conducted in 1998 by R/V Kairei, Japan Agency for Marine-Earth Science and Technology, using a SeaBeam 2112 multibeam echosounder. The SeaBeam 2112 operates at $12 \mathrm{kHz}$ with a $2^{\circ}$ by $2^{\circ}$ beam width and can produce up to 149 beams across a $150^{\circ}$ wide swath. The Kairei's sonar appears to achieve about an $80^{\circ}$ swath at depths below $10,000 \mathrm{~m}$ (Nakanishi 2011a). Based on the results of the regional bathymetric survey in 1998, R/V Kairei carried out a more focused bathymetric survey in 1999. Ship tracks were designed to cross the deepest points determined by the 1998 survey in each depression (Fig. 2a). In 2002, R/V Kairei conducted a detailed bathymetric grid survey with an interval of 6 arc seconds (about $180 \mathrm{~m}$ ) around the candidate site for the deepest seafloor. The ship speed during the survey in 1998 was 10-15 knots; however, in 1999 and 2002, a slower speed of about 5 knots was used to reduce the spacing of bathymetric data.

To process the bathymetric data and to make maps, MB-System (Caress and Chayes 1996), Generic Mapping Tools (Wessel and Smith 1998), and Marine Geophysics Basic Tools (MAGBAT; Tamaki et al. 1992) were used. Bathymetric data were passed through a despiking algorithm that filtered the unflagged data automatically using MB-System's filtering tool, mbclean. All beams were then manually edited using mbedit, MB-System's visually interactive ping-editing tool, to remove bad beams missed during the filtering step and to revive good beams flagged incorrectly.

To increase the reliability of bathymetric data, we constructed sound-velocity profiles of each cruise from the continuous measurements of vertical conductivity, temperature, and depth (CTD). CTD measurements down to about $10,780 \mathrm{~m}$ were simultaneously carried out by the instrument in ROV Kaiko during its dives in the 1998 and 1999 cruises. Because of the lack of CTD measurements in depths shallower than $20 \mathrm{~m}$, sound-velocity profiles in depths shallower than 20 $\mathrm{m}$ were made using expendable bathythermographs during each cruise. The sound velocity at sea surface was automatically measured during the surveys by the sound velocity-meter unit of the Kairei's SeaBeam 2112. We used Del Grosso's (1974) equation to calculate sound velocities. For the bathymetric data obtained in the 2002 cruise, we adopted the sound-velocity profiles made from the CTD measurements in the 1999 cruise because the CTD instrument was malfunctioning during the 2002 cruise. The absolute accuracy of sound speeds by CTD measurements is something better than $0.5 \mathrm{~m} / \mathrm{s}$ (Sea-Bird Electronics, Inc. 2004). The relative sound velocity uncertainty due to the error of CTD measurements is less than $0.05 \mathrm{~m} / \mathrm{s}$, which does not have efficient effect to estimate depth (Hammerstad 2001).

Positioning was achieved using the Skyfix differential global positioning system, a GPS positioning system that is based on clock and orbit corrections supplied by NASA's Jet Propulsion Laboratory, with a mean accuracy of $<3-5 \mathrm{~m}$ (Johnston 1994). This navigation system made it possible to determine the location of the deepest place more accurately than in previous surveys. The dynamic and follow up accuracies of the gyrocompass on R/V Kairei, Yokogawa CMZ500, are within $\pm 0.75^{\circ} \times$ secant(latitude) and within $0.1^{\circ}$ or less, respectively. The vertical reference unit in the Kairei's SeaBeam2112 is Datawell HIPPY 120C Mark II, which is commonly used in SeaBeam systems. Asada and Yabuki (2001) reported that the HIPPY-120C on S/V Kaiyo of Hydrographic and Oceanographic Department, Japan Coast Guard, provided an accuracy of a few $\mathrm{cm}$ for the heave measurement and accuracy of $0.05^{\circ}$ for the rolling and pitching.

The SeaBeam 2112 system is capable of a depth accuracy (per-beam repeatability) of $0.5 \%$ of 
water depth on at least $90 \%$ of the beams. The depth accuracy of the Kairei's Seabeam 2112 is better than $0.5 \%$ of water depth in deeper than $9,000 \mathrm{~m}$ of water depth and that of center beam is better than $0.1 \%$ of water depth (Nakanishi 2011a). The scatter in the raw bathymetric data makes it difficult to determine a maximum depth with more accuracy than has been reported in previous works. Consequently, we gridded the bathymetric data to reduce the scatter using a Gaussian weighted average (Caress and Chayes 1996) for each survey. We determined that a 250-m grid spacing should be used because the beam interval across the track is about $190 \mathrm{~m}$ and that along the track is $100-200 \mathrm{~m}$. We used all beam data from the 1998 and 1999 surveys, but we used only center beam data for the 2002 survey to increase precision in depth and position measurements.

\section{Results}

Topographic features around the Challenger Deep

The bathymetric map (Fig. 2b) shows the change in strike of the trench axis around $142^{\circ} 20^{\prime} \mathrm{E}$, being $\mathrm{N} 85^{\circ} \mathrm{E}$ to the east and $\mathrm{N} 80^{\circ} \mathrm{E}$ to the west of that longitude. Three en echelon depressions are located along the trench axis, and each depression is elongated in an about $\mathrm{N} 75^{\circ} \mathrm{E}$ direction, which is not parallel with the trench axis (Fig. 3). The depressions bounded at the $10,850 \mathrm{~m}$ contour in Fig. 3 are $6-10 \mathrm{~km}$ long and about $2 \mathrm{~km}$ wide. ROV Kaiko dives showed that the seafloor of the western depression is soft and very smooth (Hashimoto 1998, 2002; Barry and Hashimoto 2009).

The other remarkable topographic feature in the study area is a set of many elongated ridges and escarpments, which are accompanied by plate bending on the outer slope (Fig. 2c). Our map reveals two distinct strikes for these structures, although previous works (e.g., Fryer et al. 2003) reported that their strikes are uniformly parallel to the trench axis. One strike is $\mathrm{N} 85^{\circ} \mathrm{E}$, the same as that of the trench axis around Challenger Deep. The other is $N 70^{\circ} \mathrm{E}$ and oblique to that of the trench. The structures parallel to the trench axis are located only near the trench axis. The strike of a trench and the inherited seafloor spreading fabric in the subducting plate are commonly considered to be factors controlling the strike of elongated topographic structures on the oceanward slope (e.g., Masson 1991; Kobayashi et al. 1998; Nakanishi 2011b). The control of the inherited seafloor spreading fabric operates when it is oblique to the trench axis by less than $25-$ $30^{\circ}$. In all other cases, the elongated topographic structures are parallel or subparallel to the trench axis (Masson 1991; Kobayashi et al. 1998; Nakanishi 2011b). The discrepancy between the elongated structures striking $\mathrm{N} 70^{\circ} \mathrm{E}$ and the trench axis implies that the structures result from reactivation of the seafloor spreading fabric.

The seafloor spreading fabric in the study area is obscured by the absence of magnetic anomaly lineations. The Japanese Lineation set, which is a Mesozoic magnetic anomaly lineation, exists in the East Mariana Basin, east of the Mariana Trench (Nakanishi et al. 1992a), leading Nakanishi et al. (1992b) to propose that the subducting plate along the southern part of the Mariana Trench is a part of the Pacific plate formed in the Mesozoic. The Japanese Lineation set has two strikes. Lineations older than chron M21 (about $148 \mathrm{Ma}$ ) strike $\mathrm{N} 45^{\circ} \mathrm{E}$, and those younger than chron M20 (about $147 \mathrm{Ma}$ ) strike $\mathrm{N} 70^{\circ} \mathrm{E}$. The strike of the elongated structures south of the trench is the same as that of lineations younger than chron M20. If the elongated structures are caused by reactivation of the seafloor spreading fabric, the age of the subducting plate in the study area is younger than chron M20 and not the same as that of the East Mariana Basin. This indicates that the age of the subducting plate is not the cause of the great depth of the Challenger Deep.

The topographic expression of the elongated structures is a half graben with ridge and escarpment rather than full graben. The spacing of ridges is 3-5 km, and their heights are 200-400 m. Full-graben structure generally develops parallel to the trench axis (Masson 1991; Ranero et al. 2005; Nakanishi 2011b). Studies of other trenches (e.g., Ranero et al. 2005; Nakanishi 2011b) have also shown that the dominant topographic expression is a half graben in places where the seafloor spreading fabric has been reactivated. The studies support that the elongated structures in the study area are the result of a reactivation of the seafloor spreading fabric.

\section{The deepest place in Challenger Deep}

The regional bathymetric map made from the data obtained in 1998 shows that the greatest depths in the eastern, central, and western depressions are 10,922 $\pm 74 \mathrm{~m}, 10,898 \pm 62 \mathrm{~m}$, and 10,908 \pm 36 
$\mathrm{m}$, respectively, making the eastern depression the deepest of the three (Fig. 3, Table 3). The western depression in the 1998 survey had a much larger number of data points because the dive sites of ROV Kaiko were located there and bathymetric data were collected between the dives. The uncertainty of the depths is calculated as two times the standard deviation of the data within a 380m-diameter circle centered on the deepest places, because a multibeam echosounder beam represents an average depth over the beam footprint, which at depths of about 10,900 $\mathrm{m}$ has a 380$\mathrm{m}$ diameter (radius $=10,900 \times \tan \left(1^{\circ}\right)$ ). The standard deviations of the eastern, central, and western depressions are 37.2, 31.1, and $18.2 \mathrm{~m}$, respectively (Table 3). The larger standard deviations of the eastern and central depressions are the result of the smaller number of data points and the configuration of ship tracks (Fig. 2).

To confirm the accuracy of the bathymetric grid file, we compared the depths at the dive sites of ROV Kaiko in the 1998 cruise extracted from the bathymetric grid file with the depth data obtained by a manometer installed on the vehicle of ROV Kaiko (Fig. 3). The positioning accuracy for the vehicle of ROV Kaiko using the Long Base Line acoustic navigation system is within $25 \mathrm{~m}$ in any depth (Kyo et al. 1995).

The precision of the manometer is $0.025 \%$ of its full scale, that is, less than $3 \mathrm{~m}$ at a depth of $10,000 \mathrm{~m}$. The discrepancy between the bathymetric data of the bathymetric grid and the depth data of the manometer is about $\pm 2 \mathrm{~m}$, indicating that our bathymetric grid file is in good agreement with the manometer data. The sediment in the Challenger Deep is very soft (Barrry and Hashimoto 2009). In soft sediment, acoustic beams from SeaBeam 2112 may penetrate the seafloor and result in a deeper depth than the true depth. The consistency of our bathymetric data with the depth data of the manometer indicates that the effect of penetration of acoustic beams in soft sediment is negligible. The agreement also validates our estimation of depth using the sound speed profiles.

On 31 May 2009, the hybrid remotely operated vehicle (HROV) Nereus reached a depth of $10,903 \mathrm{~m}$ at $11^{\circ} 22.1^{\prime} \mathrm{N}, 142^{\circ} 35.4^{\prime} \mathrm{E}$ in the eastern depression of the Challenger Deep (Bowen et al. 2009; Fletcher et al. 2009; Table 2). The depth of the landing site, $10,903 \mathrm{~m}$, is $14 \mathrm{~m}$ shallower than that of our result. The discrepancy seems to be the result of the precision of navigation of the dive because it was positioned without long-baseline navigation (Whitcomb et al. 2010).

The cross track survey in the $1999 \mathrm{R} / \mathrm{V}$ Kairei cruise shows that the greatest depths in the eastern, central, and western depressions are 10,920 $\pm 10 \mathrm{~m}, 10,894 \pm 14 \mathrm{~m}$, and 10,907 $\pm 13 \mathrm{~m}$, respectively, which supports the results of the 1998 survey (Fig. 3, Table 3). The discrepancy between the 1998 and 1999 surveys in the position of the deepest places in each depression is less than $360 \mathrm{~m}$ (Table 3), which is smaller than the diameter of the footprint around the center beam. We concluded that the deepest places in each depression determined by the 1998 and 1999 surveys are in the same positions. The detailed grid survey in 2002 showed that the deepest site is located around $11^{\circ} 22.260^{\prime} \mathrm{N}, 142^{\circ} 35.589^{\prime} \mathrm{E}$, with a depth of $10,919.7 \mathrm{~m}$ (Fig. 4), about $290 \mathrm{~m}$ southeast of the deepest site determined by S/V Takuyo in 1984 and about $240 \mathrm{~m}$ east of the deepest place determined by the 1998 survey. The distances are again smaller than the footprint of the center beam. We conclude that our result is compatible with that determined by S/V Takuyo.

There are 19 sounding points in a circle $380 \mathrm{~m}$ in diameter at the center of the deepest point, and the depth ranges from 10,915 $\mathrm{m}$ to $10,926 \mathrm{~m}$ within that circle (the red broken circle in Fig. 4). The mean, median, and mode of the data are all $10,920 \mathrm{~m}$, and the standard deviation is $2.5 \mathrm{~m}$. We consequently recognize the deepest location in the Challenger Deep to be $10,920 \pm 5 \mathrm{~m}$, which is the same as that determined by GEBCO but with a lower uncertainty. Our result also indicates that the $95 \%$ of depth differences repeatability of the center beam is better than $0.05 \%$ of depth at a depth of about $10,900 \mathrm{~m}$.

\section{Conclusions}

Three bathymetric surveys by R/V Kairei construct a precise bathymetric map of the Challenger Deep and reveal the following:

1. The Challenger Deep has three depressions with depths greater than $10,850 \mathrm{~m}$.

2. Elongated topographic structures accompanied by plate bending exist in the oceanward slope of the Challenger Deep.

3. The elongated structures have two strikes. One is $\mathrm{N} 85^{\circ} \mathrm{E}$ and the same as the trench axis. The other is $\mathrm{N} 70^{\circ} \mathrm{E}$.

4. Most bending-related structures, except those near the trench axis, were formed by reactivation of seafloor spreading fabric.

5. The deepest seafloor in the world is located in the eastern part of the eastern depression at a 
depth of $10,920 \pm 5 \mathrm{~m}$.

Acknowledgments We thank the captains, radio offices, technical staff, and other crew of R/V Kairei who made it possible to collect bathymetric data on the 1998, 1999, and 2002 cruises. We thank Robert L. Fisher for providing useful information about the previous bathymetric surveys of the Challenger Deep and echosounding of trenches. We acknowledge Toshinobu Mikagawa and Louis L. Whitcomb for information about the dives of the ROV Kaiko and HROV Nereus, respectively. We acknowledge the staff of L-3 Communications ELAC Nautik for information of SeaBeam 2112. We are grateful to Steve C. Cande for suggesting a number of improvements to the manuscript. We thank the editor Amy Draut and anonymous reviewers for constructive input and suggestions for improvements. MN is grateful to Kensaku Tamaki for support of this work.

\section{References}

Asada A, Yabuki T (2001) Synthetic aperture technique applied to a multi-beam echo sounder. Earth Planets Space 53:321-326

Barry JP, Hashimoto J (2009) Revisiting the Challenger Deep Using the ROV Kaiko. Mar Technol Soc J 43:77-78. doi:10.4031/MTSJ.43.5.27

Bird P (2003) An updated digital model for plate boundaries. Geochem Geophys Geosyst 4. doi:10.1029/2001GC000252

Bowen AD, Yoerger DR, Taylor C, McCabe R, Howland J, Gomez-Ibanez D, Kinsey JC, Heintz M, McDonald G, Peters D, Bailey J, Shank T, Whitcomb LL, Martin SC, Webster SE, Jakuba MV, Young C, Buescher J, Fletcher B, Fryer P Hulme S (2009) Field trials of the Nereus hybrid underwater robotic vehicle in the Challenger Deep of the Mariana Trench. In Proc IEEE/MTS OCEANS Conf Exhib Biloxi MS Oct 2009. pp 1-10

Caress D, Chayes DN (1996) Improved procession of Hydrosweep DS Multibeam Data on the R/V Maurice Ewing. Mar Geophys Res. 18:631-650. doi: 10.1007/BF00313878

Carruthers JN, Lawford AL (1952) The deepest oceanic sounding. Nature 169:601-603. doi:10.1038/169601a0

Del Grosso VA (1974) New equation for the speed of sound in natural waters (with comparisons to other equations). J Acoust Soc Am 56:084-1091. doi: 10.1121/1.1903388

Fisher RL (2009) Meanwhile, Back on the Surface: Further Notes on the Sounding of Trenches. Mar Technol Soc J 43:16-19. doi:10.4031/MTSJ.43.5.7

Fisher RL, Hess HH (1963) Trenches. In Hill MN (ed) The Sea, 3. Wiley-Interscience, New York, pp 411-436

Fletcher B, Bowen A, Yoerger DR, Whitcomb LL (2009) Journey to the Challenger Deep: 50 years later with the Nereus hybrid remotely operated vehicle. Mar Technol Soc J 43:65-76. doi: 10.4031/MTSJ.43.5.26

Fryer P, Becker N, Appelgate B, Martinez F, Edwards M, Fryer G (2003) Why is the Challenger Deep so deep?. Earth Planet Sci Lett 211:259-269

Fujimoto H, Fujiwara T, Kong L (1993) Sea Beam survey over the Challenger Deep revisited. in: Preliminary Report of the Hakuho-Maru Cruise KH92-1. Ocean Research Institute, the University of Tokyo, Tokyo, pp 26-27

Fujioka K, Okino K, Kanamatsu T (2002) Morphology and origin of the Challenger Deep in the Southern Mariana Trench. Geophys Res Lett 29:1372. doi:10.1029/2001GL013595

Gaskell TF, Swallow JC, Ritchie GS (1953) Further notes on the greatest oceanic sounding and the topography of the Marianas Trench. Deep-Sea Res 1:60-63. doi:10.1016/01466313(53)90009-4

Gvirtzman Z, Stern RJ (2004) Bathymetry of Mariana trench-arc system and formation of the Challenger Deep as a consequence of weak plate coupling. Tectonics 23:TC2011. doi:10.1029/2003TC001581

Hammerstad E (2001) Multibeam echo sounder accuracy. EM Technical Note. Internal Kongsberg Simrad Publication

Hanson PP, Zenkevich NL, Sergeev UV, Udintsev GB (1959) Maximum depths of the Pacific Ocean. Priroda 6:84-88 (in Russian)

Hashimoto J (1998) Onboard report of KR98-05 cruise in the Challenger Deep. RV KAIREI/ROV KAIKO. JAMSTEC, Yokosuka 
Hashimoto J (2002) KR02-13 KAREI/KAIKO cruise in the Challenger Deep. JAMSTEC, Yokosuka

Hydrographic Department, Japan Marine Safety Agency (1984) Mariana Trench survey by the "Takuyo". Int Hydrogr Bull Spt:351-352

Johnston GT (1994) Comparison of two multi-site reference station differential GPS. J Navig 47:305-322. doi: 10.1017/S037346330001225X

Kobayashi K, Nakanishi M, Tamaki K, Ogawa Y (1998) Outer slope faulting associated with western Kuril and Japan trenches. Geophys J Int 134:356-372. doi:10.1046/j.1365246x.1998.00569.x

Kyo M, Miyazaki E, Tsukioka S, Ochi H, Amitani Y, Tsuchiya T, Aoki T, Takagawa S (1995) The sea trial of Kaiko, the full ocean depth research ROV. OCEANS'95 MTS/IEEE Proceedings. pp 1991-1996. doi:10.1109/OCEANS.1995.528882

Masson DC (1991) Fault patterns at outer trench walls. Mar Geophys Res doi:13:209-225. 10.1007/BF00369150

Miller MS, Gorbatov A, Kennett BLN (2006) Three-dimensional visualization of a near-vertical slab tear beneath the southern Mariana arc. Geochem Geophys Geosyst 7:Q06012. doi: $10.1029 / 2005 \mathrm{GC} 001110$

Nakanishi M (2011a) Field evaluation of sounding accuracy in the multi-narrow beam echosounder in deeper than 9,000 m of water depth. Jpn Soc Mar Sur Techno 23 in press (Japanese with English abstract and figure captions)

Nakanishi M (2011b) Bending-related topographic structures of the subducting plate in the northwestern Pacific Ocean. In Ogawa Y, Anma R, Dilek Y (ed) Accretionary prisms and convergent margin tectonics in the northwest Pacific Basin, Modern Approaches in Solid Earth Sciences, vol. 8, Springer, in press

Nakanishi M, Tamaki K, Kobayashi K (1992a) Magnetic anomaly lineations from Late Jurassic to Early Cretaceous in the west-central Pacific Ocean. Geophys J Int 109:701-719. doi: 10.1111/j.1365-246X.1992.tb00126.x

Nakanishi M, Tamaki K, Kobayashi K (1992b) A new Mesozoic isochron chart of the northwestern Pacific Ocean: Paleomagnetic and tectonic implications. Geophys Res Lett 19:693-696. doi:10.1029/92GL00022

Piccard J, Dietz RS (1961) Seven Miles Down; The Story of the Bathyscaph Trieste. GT Putnam's Sons.

Ranero CR, Villasenor A, Phipps Morgan J, Weinrebe W (2005) Relationship between bendfaulting at trenches and intermediate-depth seismicity. Geochem Geophys Geosyst 6:Q12002, doi:10.1029/2005GC000997

Sea-Bird Electronics, Inc (2004) Determination of Sound Velocity from CTD Data. Sea-Bird Application Note 6, Sea-Bird $\quad$ Electronics, Inc. http://www.seabird.com/application_notes/AN06.htm. Accessed 6 April 2011

Smith WHF, Sandwell DT (1997) Global sea floor topography from satellite altimetry and ship depth soundings. Science 277:1956-1962. doi: 10.1126/science.277.5334.1956

Takagawa S, Aoki T, Kawana I (1997) Diving to Mariana Trench by Kaiko. Recent Adv Mar Sci Technol 96:89-96

Taira K, Yanagimoto D, Kitagawa S (2005) Deep CTD Casts in the Challenger Deep, Mariana Trench. J Oceanogr 61:447-454

Tamaki K, Nakanishi M, Oshida A, Sayanagi K (1992) A universal marine geophysics data processing system. Bull Ocean Res Inst, 30. Ocean Research Institute, the University of Tokyo, Tokyo

Thomson, CW, Murray J (1895) Report of the scientific results of the voyage of H.M.S. Challenger during the years 1873-76 under the command of Captain Georges S. Nares and the late Captain Frank Tourle Thomson, HM Governement, London

Wessel P, Smith WHF (1998) New, improved version of Generic Mapping Tools released, EOS Trans AGU, 79:579

Whitcomb LL, Jakuba MV, Kinsey JC, Martin SC, Webster SE, Howland JC, Taylor CL, GomezIbanez D, Yoerger DR (2010) Navigation and control of the nereus hybrid underwater vehicle for global ocean science to 10,903 m Depth: Preliminary Results. In Proc IEEE Intl Conf Robot Auto Anchorage May, pp 594-600. doi:10.1109/ROBOT.2010.5509265 


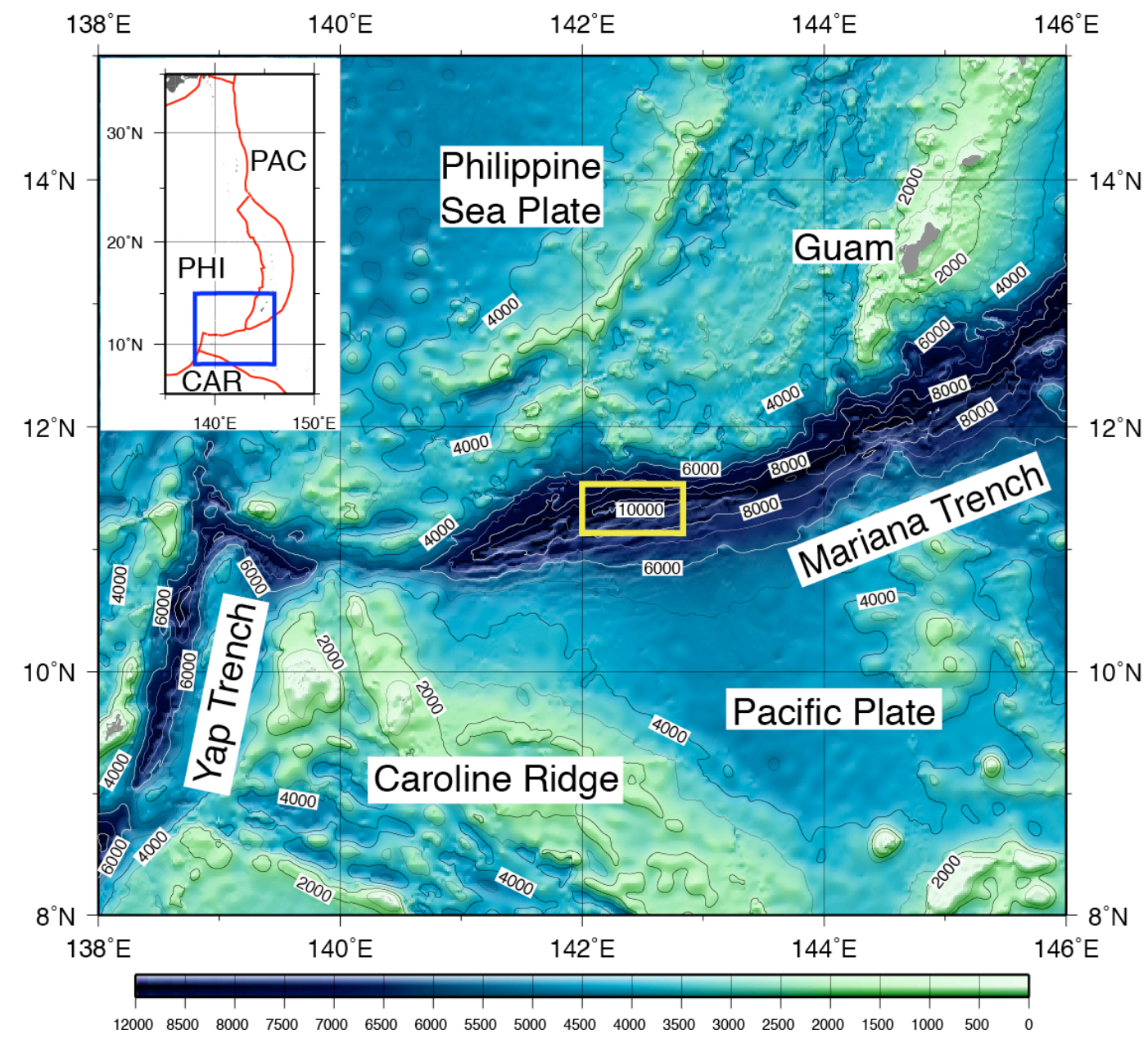

Fig. 1 Bathymetric chart around the southern Mariana Trench (contour interval $=1000 \mathrm{~m}$ ).

Seafloor topography is from Smith and Sandwell (1997). White contour lines indicate depths of deeper than $6,000 \mathrm{~m}$. The yellow rectangle encompasses the study area (Fig. 2). The index map shows the location of this map relative to other northwest Pacific features. The red lines represent the present plate boundaries from Bird (2003). PAC, PHI, and CAR denote Pacific, Philippine Sea, and Caroline plates, respectively 


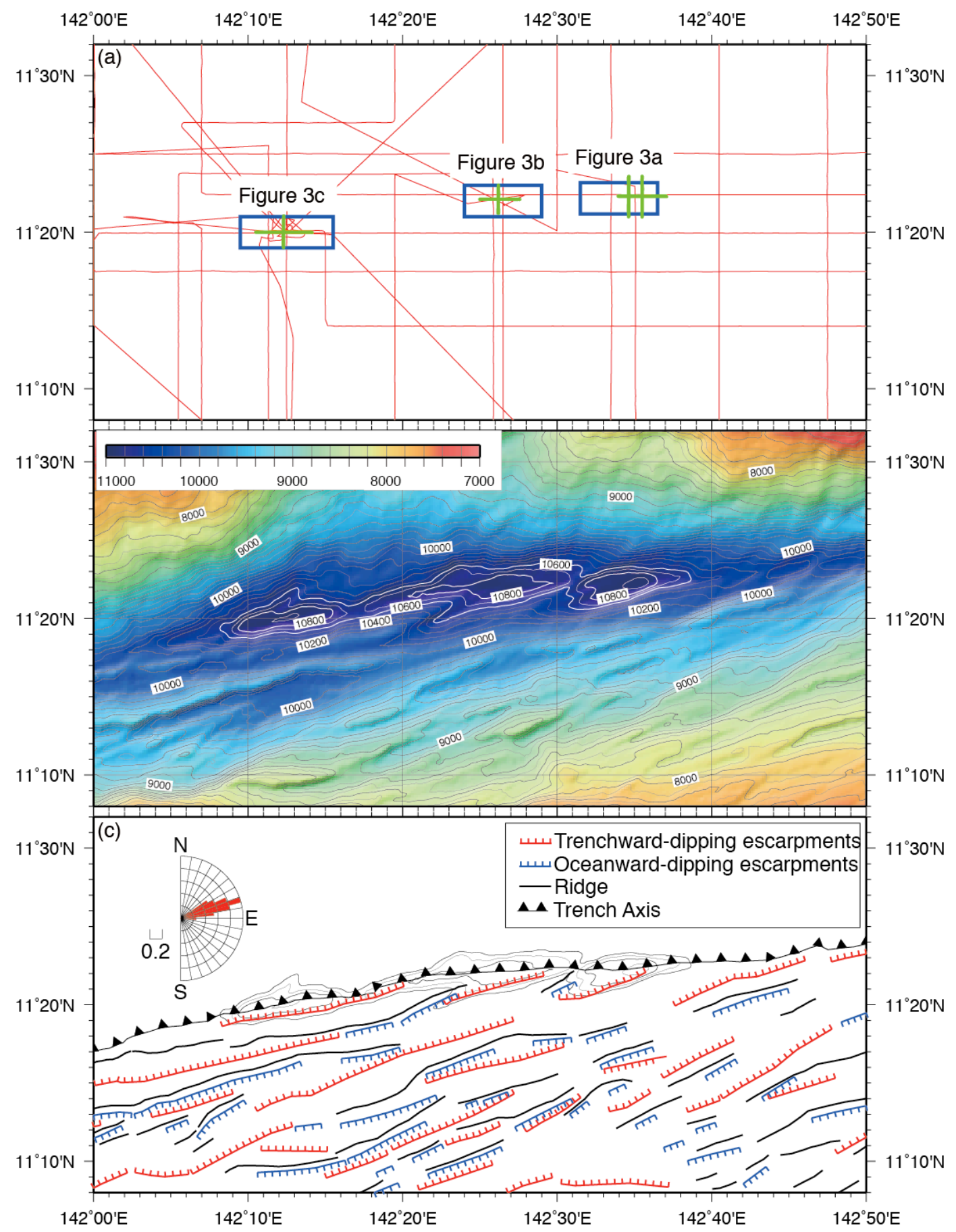

Fig. 2 (a) Track chart of the 1998 and 1999 R/V Kairei cruises used in this study. The blue rectangles represent the areas shown in Fig. 3. Red and green lines are tracks of the cruises in 1998 and 1999, respectively. (b) Bathymetric map (contour interval $=100 \mathrm{~m}$ ). White contour lines indicate depths of deeper than $10,600 \mathrm{~m}$. (c) Distribution of topographic structures related to plate bending. Rose diagram shows the strikes of bending-related topographic structures 


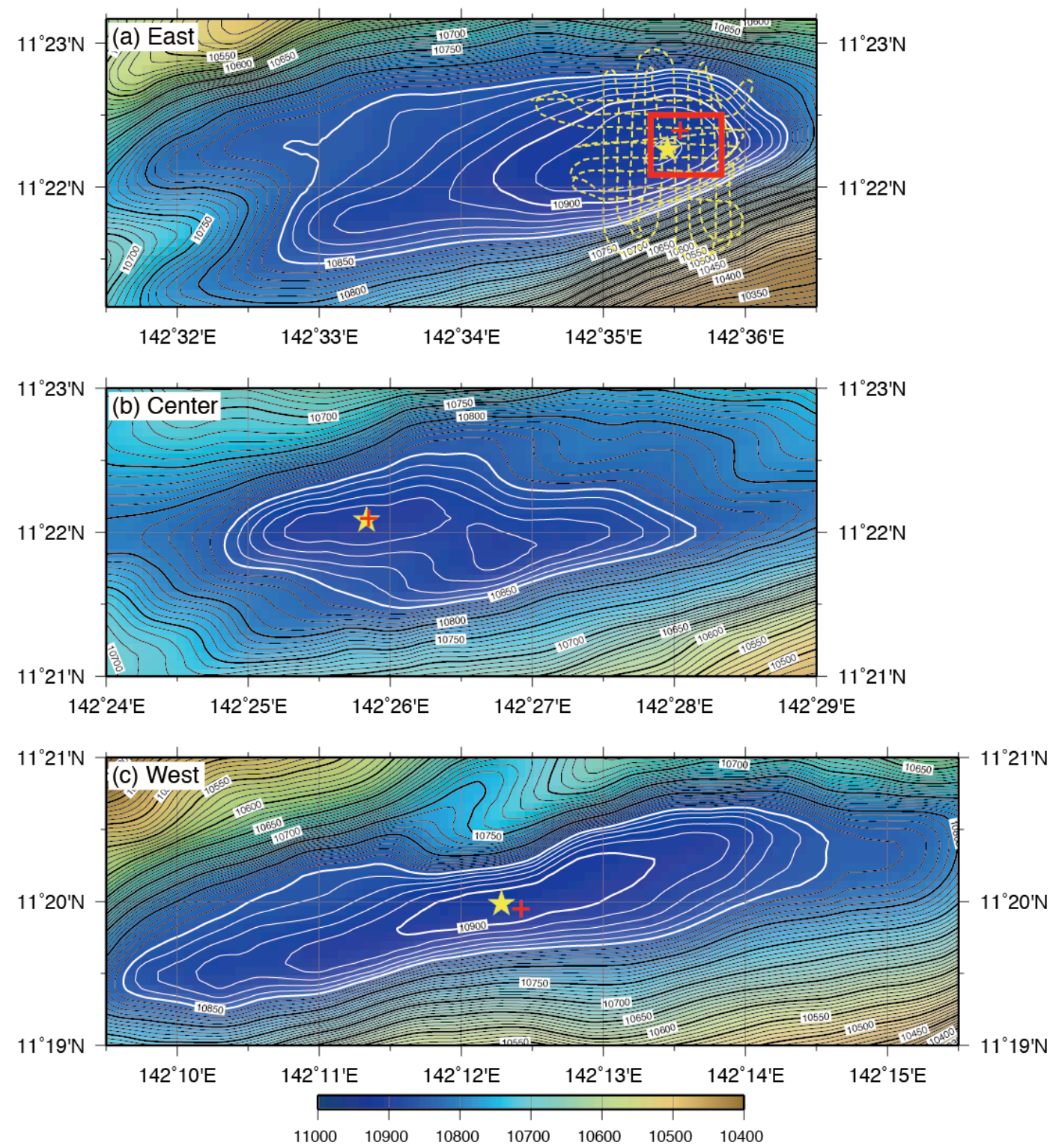

Fig. 3 Bathymetric maps of three depressions made using the bathymetric data of the $1998 \mathrm{R} / \mathrm{V}$ Kairei survey (contour interval $=10 \mathrm{~m}$ ). White contour lines indicate depths of 10,850 and 10,900 $\mathrm{m}$. Yellow stars represent the deepest points in each depression determined by the $1998 \mathrm{R} / \mathrm{V}$ Kairei survey, and red crosses are the selected dive sites of ROV Kaiko from 1995 to 1999 (Tables 2 and 3). The red box in (a) encompasses the area shown in Fig. 4, and the yellow dashed lines show the track lines of the $2002 \mathrm{R} / \mathrm{V}$ Kairei survey 


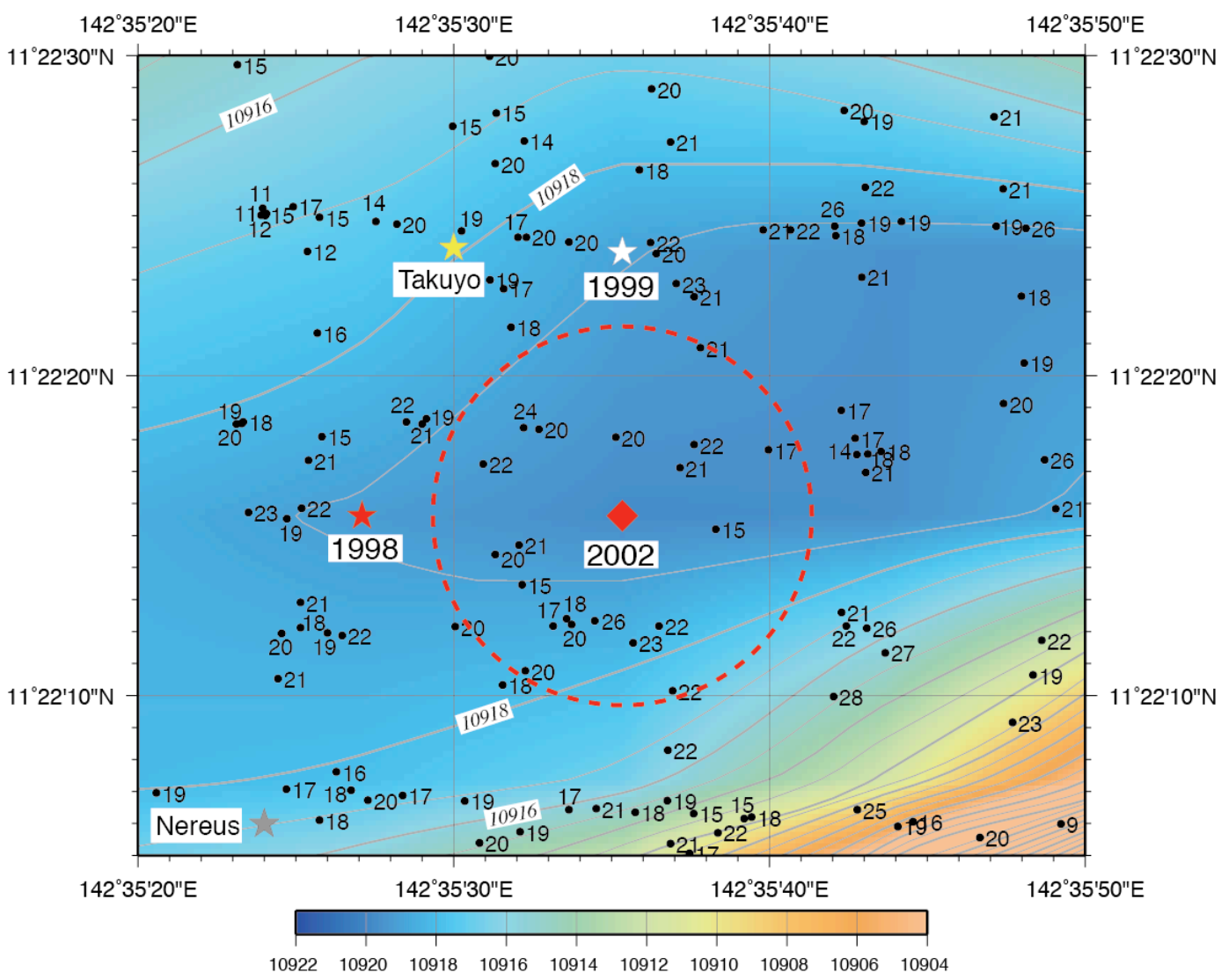

Fig. 4 Data plot of the center beams obtained during the 2002 R/V Kairei survey with 1-m contour lines superimposed for reference. Numbers show depths after subtracting 10,900. The red diamond is the deepest place determined in the $2002 \mathrm{R} / \mathrm{V}$ Kairei survey. Red, white, and yellow stars represent the deepest seafloors determined by the data from the $1998 \mathrm{R} / \mathrm{V}$ Kairei survey, the 1999 R/V Kairei survey, and the 1984 S/V Takuyo survey, respectively. The gray star shows the dive site of HROV Nereus in 2009 (Table 2). The Red dashed circle is the beam width of the center beam at $10,900 \mathrm{~m}$ 
Table 1 Selected sounding results in the Challenger Deep

\begin{tabular}{|c|c|c|c|c|c|}
\hline \multirow{2}{*}{ Year } & \multirow{2}{*}{ Vessel } & \multirow{2}{*}{$\begin{array}{c}\text { Depth } \\
\text { (m) }\end{array}$} & \multicolumn{2}{|c|}{ Position } & \multirow{2}{*}{ Reference } \\
\hline & & & Latitude & Longitude & \\
\hline 1875 & HMS Challenger & 8,184 & $11^{\circ} 24^{\prime} \mathrm{N}$ & $143^{\circ} 16^{\prime} \mathrm{E}$ & Thomson and Murray (1895) \\
\hline 1951 & Challenger VIII & $10,863 \pm 35$ & $11^{\circ} 19^{\prime} \mathrm{N}$ & $142^{\circ} 15^{\prime} \mathrm{E}$ & Carruthers and Lawford (1952) \\
\hline 1957 & Vitiaz & $11,034 \pm 50$ & $11^{\circ} 20.9^{\prime} \mathrm{N}$ & $142^{\circ} 11.5^{\prime} \mathrm{E}$ & Hanson et al. (1959) \\
\hline 1959 & Stranger & $10,850 \pm 20$ & $11^{\circ} 20.0^{\prime} \mathrm{N}$ & $142^{\circ} 11.8^{\prime} \mathrm{E}$ & Fisher and Hess (1963) \\
\hline 1962 & Spencer F. Baird & $10,915 \pm 20$ & $11^{\circ} 20.0^{\prime} \mathrm{N}$ & $142^{\circ} 11.8^{\prime} \mathrm{E}$ & Fisher and Hess (1963) \\
\hline 1975 & $\begin{array}{l}\text { Thomas } \\
\text { Washington }\end{array}$ & $10,915 \pm 10$ & $11^{\circ} 20.0^{\prime} \mathrm{N}$ & $142^{\circ} 11.8^{\prime} \mathrm{E}$ & $\begin{array}{l}\text { R. L. Fisher (personal } \\
\text { communication, 1998, 2010) }\end{array}$ \\
\hline 1980 & $\begin{array}{l}\text { Thomas } \\
\text { Washington }\end{array}$ & $10,915 \pm 10$ & $11^{\circ} 20.0^{\prime} \mathrm{N}$ & $142^{\circ} 11.8^{\prime} \mathrm{E}$ & $\begin{array}{l}\text { R. L. Fisher (personal } \\
\text { communication, 1998, 2010) }\end{array}$ \\
\hline 1984 & Takuyo & $10,924 \pm 10$ & $11^{\circ} 22.4^{\prime} \mathrm{N}$ & $142^{\circ} 35.5^{\prime} \mathrm{E}$ & $\begin{array}{l}\text { Hydrographic Department, Japan } \\
\text { Marine Safety Agency (1984) }\end{array}$ \\
\hline 1992 & Hakuho-maru & 10,933 & $11^{\circ} 22.4^{\prime} \mathrm{N}$ & $142^{\circ} 35.5^{\prime} \mathrm{E}$ & Fujimoto et al. (1993) \\
\hline 1992 & Hakuho-maru & 10,989 & $11^{\circ} 22.6^{\prime} \mathrm{N}$ & $142^{\circ} 35.0^{\prime} \mathrm{E}$ & Taira et al. (2005) \\
\hline 1998 & Kairei & $10,938 \pm 10$ & $11^{\circ} 20.34^{\prime} \mathrm{N}$ & $142^{\circ} 13.2^{\prime} \mathrm{E}$ & Fujioka et al. (2002) \\
\hline
\end{tabular}


Table 2 Selected dive sites in the Challenger Deep. The dive sites of ROV Kaiko and HROV Nereus are shown in Figs 2 and 3, respectively.

\begin{tabular}{cccccc}
\hline \multirow{2}{*}{ Year } & $\begin{array}{c}\text { Vehicle } \\
\text { (Dive number) }\end{array}$ & $\begin{array}{c}\text { Depth } \\
(\mathrm{m})\end{array}$ & Latitude & Longitude & Reference \\
\hline 1960 & $\begin{array}{c}\text { Bathyscaph } \\
\text { Trieste }\end{array}$ & $10,913 \pm 5$ & $11^{\circ} 19^{\prime} \mathrm{N}$ & $142^{\circ} 15^{\prime} \mathrm{E}$ & Piccard and Dietz (1961) \\
1995 & $\begin{array}{c}\text { ROV Kaiko } \\
\text { (Test dive) }\end{array}$ & 10,911 & $11^{\circ} 22.39^{\prime} \mathrm{N}$ & $142^{\circ} 35.54^{\prime} \mathrm{E}$ & Takagawa et al. (1997) \\
1996 & $\begin{array}{c}\text { ROV Kaiko } \\
\text { (Dive 21) } \\
\text { ROV Kaiko } \\
\text { (Dive 71) }\end{array}$ & 10,898 & $11^{\circ} 22.10^{\prime} \mathrm{N}$ & $142^{\circ} 25.85^{\prime} \mathrm{E}$ & Takagawa et al. (1997) \\
2009 & $\begin{array}{c}\text { HRV Nereus } \\
\text { (Dive 11) }\end{array}$ & 10,903 & $11^{\circ} 22.1^{\prime} \mathrm{N}$ & $142^{\circ} 35.4^{\prime} \mathrm{E}$ & Bowen et al. (2009) \\
\hline
\end{tabular}


Table 3 Depths and positions of the deepest place in each depression determined by the 1998 and 1999 R/V Kairei surveys

\begin{tabular}{|c|c|c|c|c|c|c|c|}
\hline \multirow{2}{*}{ Depression } & \multirow{2}{*}{$\begin{array}{c}\text { Survey } \\
\text { year }\end{array}$} & \multicolumn{2}{|c|}{ Position } & \multirow{2}{*}{$\begin{array}{l}\text { Depth } \\
(\mathrm{m})\end{array}$} & \multirow{2}{*}{$\begin{array}{c}\text { Standard } \\
\text { deviation } \\
(\mathrm{m})\end{array}$} & \multirow{2}{*}{$\begin{array}{c}\text { Final } \\
\text { depth } \\
(\mathrm{m})\end{array}$} & \multirow{2}{*}{$\begin{array}{c}\text { Number } \\
\text { of data } \\
\text { points*1 }\end{array}$} \\
\hline & & Latitude & Longitude & & & & \\
\hline \multirow{2}{*}{ East } & 1998 & $11^{\circ} 22.260^{\prime} \mathrm{N}$ & $142^{\circ} 35.452^{\prime} \mathrm{E}$ & $10,922.0$ & 37.2 & $10,922 \pm 74$ & 18 \\
\hline & 1999 & $11^{\circ} 22.398^{\prime} \mathrm{N}$ & $142^{\circ} 35.589^{\prime} \mathrm{E}$ & $10,919.5$ & 5.2 & $10,920 \pm 10$ & 21 \\
\hline \multirow{2}{*}{ Center } & 1998 & $11^{\circ} 22.085^{\prime} \mathrm{N}$ & $142^{\circ} 25.833^{\prime} \mathrm{E}$ & $10,897.7$ & 31.1 & $10,898 \pm 62$ & 29 \\
\hline & 1999 & $11^{\circ} 21.986^{\prime} \mathrm{N}$ & $142^{\circ} 25.696^{\prime} \mathrm{E}$ & $10,894.7$ & 7.1 & $10,894 \pm 14$ & 43 \\
\hline \multirow{2}{*}{ West } & 1998 & $11^{\circ} 19.985^{\prime} \mathrm{N}$ & $142^{\circ} 12.283^{\prime} \mathrm{E}$ & $10,907.6$ & 18.2 & $10,908 \pm 36$ & 424 \\
\hline & 1999 & $11^{\circ} 19.924^{\prime} \mathrm{N}$ & $142^{\circ} 12.367^{\prime} \mathrm{E}$ & $10,906.6$ & 6.5 & $10,907 \pm 13$ & 47 \\
\hline
\end{tabular}

*1: Number of data points within a 380 -m-diameter circle centered on the deepest place. 